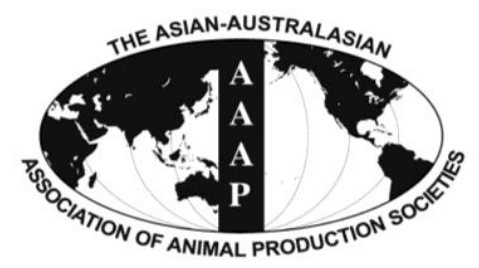

Asian-Aust. J. Anim. Sci.

Vol. 25, No. 3 : 410 - 420

March 2012

www.ajas.info

http://dx.doi.org/10.5713/ajas.2011.11212

\title{
Daily Feed Intake, Energy Intake, Growth Rate and Measures of Dietary Energy Efficiency of Pigs from Four Sire Lines Fed Diets with High or Low Metabolizable and Net Energy Concentrations
}

\author{
A. P. Schinckel*, M. E. Einstein, S. Jungst ${ }^{1}$, J. O. Matthews ${ }^{1}$, C. Booher ${ }^{1}$, T. Dreadin ${ }^{1}$, \\ C. Fralick ${ }^{2}$, E. Wilson ${ }^{1}$ and R. D. Boyd ${ }^{3}$ \\ Purdue University, Department of Animal Sciences, 915 West State Street, West Lafayette, IN 47907-2054, USA
}

\begin{abstract}
A trial was conducted to: i) evaluate the BW growth, energy intakes and energetic efficiency of pigs fed high and low density diets from 27 to $141 \mathrm{~kg} \mathrm{BW}$, ii) evaluate sire line and sex differences when fed both diets, and iii) to compare ME to NE as predictor of pig performance. The experiment had a replicated factorial arrangement of treatments including four sire lines, two sexes (2,192 barrows and 2,280 gilts), two dietary energy densities and a light or heavy target BW, 118 and $131.5 \mathrm{~kg}$ in replicates 1 to 6 and 127 and $140.6 \mathrm{~kg}$ in replicates 7 to 10 . Pigs were allocated to a series of low energy (LE, $3.27 \mathrm{Mcal}$ ME/kg) corn-soybean meal based diets with $16 \%$ wheat midds or high energy diets (HE, 3.53 to $3.55 \mathrm{Mcal} \mathrm{ME} / \mathrm{kg}$ ) with 4.5 to $4.95 \%$ choice white grease. All diets contained 6\% DDGS. The HE and LE diets of each of the four phases were formulated to have equal lysine:Mcal ME ratios. Pigs were weighed and pen feed intake (11 or 12 pigs/pen) recorded at 28-d intervals. The barrow and gilt daily feed (DFI), ME (MEI) and NE (NEI) intake data were fitted to a Bridges function of BW. The BW data of each sex were fitted to a generalized Michaelis-Menten function of days of age. ME and NE required for maintenance (Mcal/d) were predicted using functions of BW ( 0.255 and 0.179 $\mathrm{BW}^{\wedge} 0.60$ respectively). Pigs fed LE diets had decreased ADG (915 vs. $\left.945 \mathrm{~g} / \mathrm{d}, \mathrm{p}<0.001\right)$ than pigs fed HE diets. Overall, DFI was greater $(\mathrm{p}<0.001)$ for pigs fed the LE diets $(2.62 \mathrm{vs} .2 .45 \mathrm{~kg} / \mathrm{d})$. However, no diet differences were observed for MEI $(8.76 \mathrm{vs} .8 .78$ $\mathrm{Mcal} / \mathrm{d}, \mathrm{p}=0.49)$ or NEI (6.39 vs. $6.44 \mathrm{Mcal} / \mathrm{d}, \mathrm{p}=0.13)$, thereby indicating that the pigs compensated for the decreased energy content of the diet. Overall ADG:DFI (0.362 vs. 0.377) and ADG:Mcal MEI (0.109 vs. 0.113) was less ( $\mathrm{p}<0.001)$ for pigs fed LE compared to HE diets. Pigs fed HE diets had 3.6\% greater ADG:Mcal MEI above maintenance and only 1.3\% greater ADG:Mcal NEI (0.152 versus 0.150), therefore NEI is a more accurate predictor of growth and G:F than MEI.Pigs fed HE diets had 3.4\% greater ADG:Mcal MEI and $0.11 \%$ greater ADG:NEI above maintenance than pigs fed LE diets, again demonstrating that NEI is a better predictor of pig performance than MEI. Pigs fed LE diets had similar daily NEI and MEI but grew slower and less efficiently on both ME and NE basis than pigs fed HE diets. The data suggest that the midds NE value $(2.132 \mathrm{Mcal} / \mathrm{kg})$ was too high for this source or that maintenance was increased for pigs fed LE diets. (Key Words : Pig, Growth Performance, Feed Efficiency, Dietary Energy)
\end{abstract}

\section{INTRODUCTION}

The optimization of pork production systems including alternative dietary management and marketing strategies requires knowledge of pig feed intakes, growth rates and estimated measures of feed or energetic efficiency (Krick et al., 1992; de Lange and Schreurs, 1995; Schinckel et al., 2008). In the United States, high energy feed ingredients

\footnotetext{
* Corresponding Author : A. P. Schinckel. Tel : +1-765-494-4836, Fax : +1-765-494-9346, E-mail : aschinck@purdue.edu

${ }^{1}$ PIC North America, Hendersonville, TN 37075, USA.

${ }^{2}$ Swine Tek, Convoy, OH 45832, USA.

${ }^{3}$ The Hanor Company, Franklin, KY 42123, USA.

Submitted Jul. 7, 2011; Accepted Sept. 15, 2011; Revised Sept. 28, 2011
}

have been directed towards bioenergy production (i.e., corn to ethanol and animal fats to biodiesel). This has resulted in the formulation of diets that are more diverse and with decreased energy concentration. Diets with decreased concentrations may reduce the lipid accretion rates to a greater extent than protein accretion. In this case, the amount of BW gain produced per unit energy intake above maintenance may be affected by the energy concentration of the diets fed. Currently, both the ME and NE systems are used in the pork industry for diet formulation and to predict pig growth responses to diets with different feed ingredients (NRC, 1998; Noblet et al., 1999). The advantages of the NE systems have been discussed by Birkett and de Lange (2001a, b) and Noblet and Milgen (2004). 
Genetic populations of pigs differ in their growth rates, daily energy intakes, and relative rates of protein to lipid deposition (de Lange and Scheurs, 1995; Schinckel and de Lange, 1996). Genetic or gender differences in the relative amounts of energy required for maintenance, protein and lipid accretion has an impact the pigs' relative efficiency use of dietary energy from protein, lipid and carbohydrates (Birkett and de Lange, 2001a, b). Genetic differences could also exist for the pigs' ability to use diets with different composition. Differences between genetic populations for growth rates and measurements of feed or energetic efficiency could be impacted by the energy concentration of the diets fed. The objectives of this study were: i) to evaluate the BW growth, energy intakes and energetic efficiency of pigs fed high and low energy density diets from 27 to $141 \mathrm{~kg} \mathrm{BW}$, ii) to evaluate sire line and sex differences in pig growth, energy intakes and energetic efficiency when fed both high and low energy diets, and iii) to compare $\mathrm{ME}$ to $\mathrm{NE}$ as predictor of pig performance.

\section{MATERIALS AND METHODS}

\section{Animal management and data collection}

Animal procedures were consistent with the Guide for the Care and Use of Animals in Agricultural Research and Teaching FASS, 2010. Pigs (2,192 barrows and 2,280 gilts) were derived from a commercial sow farm owned by The Hanor Company and transported to Swine Tek, LLC for trial. The experiment was designed as a 10 replicates of a factorial arrangement of treatments including four sire lines, two sexes (barrows and gilts), two dietary energy densities and a light or heavy target BW. Sires from four terminal sire lines (1, 2, 3 and 4) were mated to PIC Cambrough sows. The four sire lines have different growth rates, daily feed intakes and measures of carcass composition (Schinckel et al., 2011). One group of sows was mated to the sires of each of the four sire lines each month. The goal was to breed approximately 14 sows per sire line per month. The mean number of sows bred to each sire line each month averaged 13.5 females and ranged from 8 to 19 . At total of 22 to 23 sires of each sire line were mated to sows over the 10 month period. The 10 monthly groups of sows (replicate) were bred from September 2008 to July 2009.

The birth weight of each piglet was collected. Male piglets were castrated at 5 to $7 \mathrm{~d}$ of age. Pigs were weaned at approximately $20 \mathrm{~d}$ of age and weighed in the nursery at an average of $50 \mathrm{~d}$ of age. All pigs were phase-fed the same nursery diets to an average age of $63 \mathrm{~d}$ at which time they were transported from the nursery facility to the Swine Tek research barns. Pigs were sorted into pens (11or 12 pigs/ pen) based on sire line and gender at arrival at the research building. Each pen had $7.62 \mathrm{~m}^{2}$ of floor space to provide $0.635 \mathrm{~m}^{2} / \mathrm{pig}$ with $12 \mathrm{pigs} / \mathrm{pen}$. Each pen was randomly
Table 1. Diet composition (\%) specifications for the low energy diets

\begin{tabular}{|c|c|c|c|c|}
\hline \multirow{3}{*}{ Component } & \multicolumn{4}{|c|}{ Phase of growth ${ }^{\mathrm{a}}$} \\
\hline & Grower & Grower & Finisher & Finisher \\
\hline & 1 & 2 & 1 & 2 \\
\hline Corn & 52.20 & 54.37 & 62.90 & 63.55 \\
\hline Soybean meal, dehulled & 23.15 & 21.40 & 12.9 & 12.45 \\
\hline Wheat middlings & 16.0 & 16.0 & 16.0 & 16.0 \\
\hline Corn-DDGS & 6.0 & 6.0 & 6.0 & 6.0 \\
\hline Limestone & 1.24 & 1.20 & 1.18 & 1.16 \\
\hline Salt & 0.40 & 0.40 & 0.40 & 0.40 \\
\hline L-lysine $\mathrm{HCl}$ & 0.325 & 0.30 & 0.30 & 0.175 \\
\hline DL-methionine & 0.065 & & & \\
\hline L-threonine & 0.070 & 0.075 & 0.074 & 0.014 \\
\hline Trace mineral premix ${ }^{b}$ & 0.075 & 0.075 & 0.075 & 0.075 \\
\hline Vitamin premix ${ }^{c}$ & 0.025 & 0.025 & 0.025 & 0.025 \\
\hline Potassium chloride & 0.10 & 0.10 & 0.10 & 0.10 \\
\hline Copper sulfate & 0.019 & & & \\
\hline Se premix & 0.050 & 0.050 & 0.050 & 0.050 \\
\hline Antibiotic premix & 0.278 & & & \\
\hline \multicolumn{5}{|l|}{ Calculated analysis } \\
\hline ME (Mcal/kg) & 3.271 & 3.273 & 3.273 & 3.272 \\
\hline $\mathrm{NE}(\mathrm{Mcal} / \mathrm{kg})$ & 2.356 & 2.375 & 2.400 & 2.421 \\
\hline $\operatorname{NDF}(\%)$ & 15.5 & 15.4 & 15.4 & 15.3 \\
\hline Total fat $(\%)$ & 3.8 & 3.9 & 4.0 & 4.1 \\
\hline Lysine total (\%) & 1.22 & 1.09 & 0.95 & 0.82 \\
\hline Lysine, SID (\%) & 1.05 & 0.992 & 0.79 & 0.68 \\
\hline SID lysine:NRC ME & 3.40 & 3.01 & 2.61 & 2.23 \\
\hline SID Threonine:lysine & 0.61 & 0.63 & 0.64 & 0.66 \\
\hline SID Trytophan:lysine & 0.17 & 0.18 & 0.18 & 0.19 \\
\hline SID Met+Cystine:lysine & 0.55 & 0.58 & 0.62 & 0.65 \\
\hline Calcium (\%) & 0.76 & 0.73 & 0.70 & 0.67 \\
\hline Phosphorus available (\%) & 0.30 & 0.29 & 0.28 & 0.27 \\
\hline
\end{tabular}

a Grower 1 from 27 to $58 \mathrm{~kg} \mathrm{BW}$, Grower 2 from 58 to $84 \mathrm{~kg} \mathrm{BW}$, Finisher 1 from $84 \mathrm{~kg} \mathrm{BW}$ to target BW.

${ }^{\mathrm{b}}$ Supplied per kg of diet: $\mathrm{Fe}, 100 \mathrm{mg}\left(\mathrm{FeSO}_{4}\right) ; \mathrm{Zn}, 125 \mathrm{mg}\left(\mathrm{ZnSO}_{4}\right)$; Mn, $35 \mathrm{mg}\left(\mathrm{MnSO}_{4}\right) ; \mathrm{Cu}, 15 \mathrm{mg}\left(\mathrm{CuSO}_{4}\right) ; \mathrm{I}, 0.35 \mathrm{mg}$ (EDDI); Se, $0.30 \mathrm{mg}$ $\left(\mathrm{Na}_{2} \mathrm{Se}\right)$.

c Supplied per kg of diet: vitamin A, 11,025 IU; vitamin $\mathrm{D}_{3}, 1,764 \mathrm{IU}$; vitamin $\mathrm{E}, 77 \mathrm{IU}$; vitamin $\mathrm{K}$ (menadione activity), $4.4 \mu \mathrm{g}$; riboflavin, 11 $\mathrm{mg}$; D-pantothenic acid, $33 \mathrm{mg}$; niacin, $3.3 \mathrm{mg}$; vitamin $\mathrm{B}_{12}, 44.0 \mu \mathrm{g}$; thiamine, $3.3 \mathrm{mg}$; pyridoxine, $5.5 \mathrm{mg}$; folic acid, $1.21 \mathrm{mg}$; D-biotin, 276 $\mu \mathrm{g}$.

assigned to either the high (HE) or low (LE) energy diets (Table 1) and to either light or heavy market weight. The LE and HE diets were phase fed from the test date to completion of test. For replicates 1 to 6 , the target BWs were 117.9 and $131.5 \mathrm{~kg}$. In replicates 7 to 10 , the target BWs were 127 and $140.6 \mathrm{~kg}$. Individual pig BWs were recorded for each pig every 28 to $30 \mathrm{~d}$ until the pig achieved its target BW. Pen feed intake data was collected each weigh day and when one or more pigs achieved its target BW and was removed from the pen and marketed. Pigs were transported and harvested at a commercial pork 
processing plant.

Diets were formulated to meet amino acid specifications that were established for these terminal genetic products (PIC, 2008), whereas, vitamin and mineral levels meet or exceed the NRC (1998). Diet energy differences were established using either fat or wheat midds. Diets were then balanced to a constant SID lysine:ME ratio for each growth phase. The most essential amino acids were set as a minimum SID ratio relative to lysine. The composition of each ingredient was also determined prior to formulation.

Two energy standards were utilized (ME, NE) in our valuation (Table 2). Ingredient $\mathrm{ME}$ values were derived from the NRC (1998). Net energy (NE) values for the feed ingredients were derived from NRC (1998) and Noblet et al. (1999) with 3 exceptions. The NE value for choice white grease used was different than NRC (1998). The NE value used for soybean meal (Boyd et al., 2011) was previously

Table 2. Diet composition (\%) specifications for the high energy diets

\begin{tabular}{|c|c|c|c|c|}
\hline \multirow{3}{*}{ Component } & \multicolumn{4}{|c|}{ Phase of growth ${ }^{\mathrm{a}}$} \\
\hline & Grower & Grower & Finisher & $\overline{\text { Finisher }}$ \\
\hline & 1 & 2 & 1 & 2 \\
\hline$\overline{\text { Corn }}$ & 57.90 & 61.54 & 69.66 & 71.24 \\
\hline Soybean meal, dehulled & 28.15 & 25.45 & 17.5 & 16.1 \\
\hline Corn DDGS & 6.00 & 6.00 & 6.00 & 6.00 \\
\hline Choice white grease & 4.95 & 4.50 & 4.50 & 4.50 \\
\hline Limestone & 1.125 & 1.095 & 1.07 & 1.06 \\
\hline Mono Ca-phosphate & 0.40 & 0.315 & 0.265 & 0.245 \\
\hline Salt & 0.40 & 0.40 & 0.40 & 0.40 \\
\hline L-lysine $\mathrm{HCl}$ & 0.325 & 0.300 & 0.275 & 0.175 \\
\hline DL-methionine & 0.092 & 0.062 & 0.003 & \\
\hline L-threonine & 0.085 & 0.088 & 0.076 & 0.0275 \\
\hline Trace mineral premix ${ }^{\mathrm{b}}$ & 0.075 & 0.075 & 0.075 & 0.075 \\
\hline Vitamin premix ${ }^{c}$ & 0.025 & 0.025 & 0.025 & 0.025 \\
\hline Potassium chloride & 0.10 & 0.10 & 0.10 & 0.10 \\
\hline Copper sulfate & 0.049 & & & \\
\hline Se premix & 0.05 & 0.05 & 0.05 & 0.05 \\
\hline Antibiotic premix & 0.278 & & & \\
\hline \multicolumn{5}{|l|}{ Calculated analysis } \\
\hline $\mathrm{ME}(\mathrm{Mcal} / \mathrm{kg})$ & 3.548 & 3.543 & 3.538 & 3.533 \\
\hline $\mathrm{NE}(\mathrm{Mcal} / \mathrm{kg})$ & 2.624 & 2.644 & 2.664 & 2.684 \\
\hline $\operatorname{NDF}(\%)$ & 11.2 & 11.1 & 11.1 & 11.0 \\
\hline Total fat (\%) & 8.1 & 8.1 & 8.0 & 8.0 \\
\hline Lysine total (\%) & 1.27 & 1.13 & 0.99 & 0.85 \\
\hline SID lysine (\%) & 1.16 & 1.02 & 0.89 & 0.77 \\
\hline SID lysine:NRC ME & 3.40 & 3.01 & 2.61 & 2.23 \\
\hline SID Threonine:lysine & 0.61 & 0.63 & 0.64 & 0.66 \\
\hline SID Trytophan:lysine & 0.17 & 0.17 & 0.18 & 0.18 \\
\hline SID Met+Cystine:lysine & 0.55 & 0.58 & 0.60 & 0.63 \\
\hline Calcium (\%) & 0.76 & 0.73 & 0.71 & 0.68 \\
\hline Phosphorus available (\%) & 0.30 & 0.29 & 0.28 & 0.27 \\
\hline
\end{tabular}

${ }^{\mathrm{a}}$ Grower 1 from 27 to $58 \mathrm{~kg} \mathrm{BW}$, Grower 2 from 58 to $84 \mathrm{~kg} \mathrm{BW}$, Finisher 1 from $84 \mathrm{~kg} \mathrm{BW}$ to target BW. validated via growth asays. The NE value used for wheat midds was computed using an equation that was provided by Professor K. de Lange of the NRC revision committee (personal communication). This estimate was lower than published by Boyd et al. (2010), primarily because of reduced starch content.

\section{Statistical analyses}

The BW data of each gender was fitted to a generalized Michaelis-Menten (GMM) equation (Lopez et al., 2000; Schinckel et al., 2009a). The equation has two alternative forms, $\mathrm{WT}_{\mathrm{i}, \mathrm{t}}=\left(\left(\mathrm{WT}_{\mathrm{o}} \mathrm{K}^{\mathrm{C}}\right)+\left(\mathrm{WF} \mathrm{t}^{\mathrm{C}}\right)\right) /\left(\mathrm{K}^{\mathrm{C}}+\mathrm{t}^{\mathrm{C}}\right)+\mathrm{e}_{\mathrm{i}, \mathrm{t}}$ or $\mathrm{WT}_{\mathrm{i}, \mathrm{t}}=$ $\left.\left.\mathrm{WT}_{\mathrm{o}}+\left(\left(\mathrm{WF}-\mathrm{WT}_{\mathrm{o}}\right)(\mathrm{t} / \mathrm{K})^{\mathrm{C}}\right)\right) /\left(1+(\mathrm{t} / \mathrm{K})^{\mathrm{C}}\right)\right)+\mathrm{e}_{\mathrm{i}, \mathrm{t}}$ where $\mathrm{WF}$ is mean mature $\mathrm{BW}, \mathrm{WT}_{\mathrm{o}}$ is the mean birth $\mathrm{BW}, \mathrm{t}$ is days of age, $\mathrm{K}$ is a parameter equal to the days of age in which onehalf WF is achieved and $\mathrm{C}$ is a unit less parameter related to changes in proportional growth and shape of the growth curves (Lopez et al., 2000). In this function, each pig's actual birth $\mathrm{BW}\left(\mathrm{WT}_{\mathrm{i}, \mathrm{o}}\right)$ was used. This function has an inflection point age $(\mathrm{IP}, \mathrm{d})=\mathrm{K}((\mathrm{C}-1) /(\mathrm{C}+1))^{(1 / \mathrm{C})}$ and the $\mathrm{BW}$ at the $\mathrm{IP}=\left((1+(1 / \mathrm{C})) \mathrm{WT}_{\mathrm{o}}+(1-(1 / \mathrm{C})) \mathrm{WF}\right) / 2$. In this function, $\mathrm{WF}, \mathrm{K}$ and $\mathrm{C}$ were considered as random effects.

The solution of a nonlinear model including three random parameters is difficult to obtain for the GMM function (Schinckel et al., 2009a). After preliminary analyses were completed and no solution was obtained for the three random effects models, alternative analyses were completed using each equation. The alternative analyses predicted a random effect for $\mathrm{c}_{\mathrm{i}}$ as a linear function of $\mathrm{wf}_{\mathrm{i}}\left(\mathrm{c}_{\mathrm{i}}\right.$ $\left.=\mathrm{b} \mathrm{wf}_{\mathrm{i}}\right)$ or $\mathrm{k}_{\mathrm{i}}\left(\mathrm{c}_{\mathrm{i}}=\mathrm{b} \mathrm{k}_{\mathrm{i}}\right)$. In these analyses, the fixed parameter $\mathrm{C}$ was replaced by $\mathrm{C}+\mathrm{c}_{\mathrm{i}}\left(\mathrm{C}+\mathrm{b} \mathrm{wf}_{\mathrm{i}}\right)$ or $\left(\mathrm{C}+\mathrm{b} \mathrm{k}_{\mathrm{i}}\right)$. These analyses allowed for a pig specific value of $c_{i}$ to be predicted based upon a population wide linear relationship of the predicted random effect for $c_{i}$ and $w_{i}$.

Table 3. Summary of energy values used in formulating diets (Kcal/kg as fed basis) $^{\mathrm{a}}$

\begin{tabular}{lccc}
\hline Ingredient & $\mathrm{DM} \%^{\mathrm{a}}$ & $\mathrm{ME}^{\mathrm{b}}$ & $\mathrm{NE}^{\mathrm{a}}$ \\
\hline Corn & 87.5 & 3,368 & 2,651 \\
Soybean meal, 47\% CP & 90.0 & 3,383 & 2,024 \\
Distillers dried grains w. solubles & 89.0 & 3,288 & 2,329 \\
Wheat middlings & 88.0 & 3,031 & 2,132 \\
Choice white grease & 99.6 & 7,970 & 7,162 \\
Lysine & 98.5 & 4,578 & 3,432 \\
L-threonine & 98.5 & 3,943 & 2,955 \\
DL-methionine & 98.3 & 5,521 & 4,138
\end{tabular}

${ }^{a}$ NRC (1998) ME values adjusted to actual ingredient DM (as is). Dry matter $\%$ for each ingredient at feed plant.

${ }^{b}$ Net energy (NE) estimates computed from Noblet et al. $(1993,1994)$ except for amino acids (Noblet, personal communication). The computed value for soybean meal was validated using growth bio-assay (ADG:ME intake) in ad lib. fed pigs (Boyd et al., , 2011). The NE value for wheat midds was obtained from Professor K. de Lange (personal communication) 
The BW data from each sex of pigs were fitted to the GMM function using the nonlinear mixed (NLMIXED) procedure of SAS ${ }^{\circledR}$ (SAS Institute, Inc., Cary, NC). Random effects were added in a step-wise order based on Akaike's Information Criteria (AIC) values. The addition of a predicted random effect for $\mathrm{c}_{\mathrm{i}}$ as a linear function of $\mathrm{wf}_{\mathrm{i}}$ was evaluated for each equation by comparing the AIC values. The $\mathrm{R}^{2}$ values were calculated as squared correlations between the predicted and actual observations. The RSD was calculated with the equation RSD = $\left(\sum_{t=1}^{T} \sum_{i=1}^{I}\left(\mathrm{e}_{\mathrm{i}, \mathrm{t}}\right)^{2} /(\mathrm{n}-\mathrm{p})\right)^{1 / 2}$ where $e_{i, t}$ is the residual value of the $\mathrm{i}^{\text {th }}$ pig at age $t, \mathrm{n}$ is the number of observations, and $\mathrm{p}$ is the number of parameters in the model. The NLMIXED procedure provided predicted values for the random effect of each pig, variance estimates for each random effect, covariance estimates for each pair of random effects, and the residual variance.

Predicted values for BW and ADG were predicted for each pig from the GMM function by including each pig's specific random effect. The predicted ADG's and BW's for the GMM function at five ages $(84,102,120,138$ and 156d) were fitted to a model including the fixed effects of age, replicate, sire line, diet, sex and their interactions using the MIXED procedure of SAS. Significant age by fixed effect interactions for predicted ADG indicate that the predicted growth curves are different for that specific fixed effect (Hamilton et al., 2003).

The pen daily feed, ME and NE intake data were fitted to a nonlinear function of mid-BW of each pen for each period. The Bridges function $\mathrm{DFI}_{\mathrm{i}, \mathrm{BW}}=\mathrm{C}\left(1-\exp \left(-\mathrm{M} \mathrm{BW}{ }^{\mathrm{A}}\right)\right)$ $+\mathrm{e}_{\mathrm{i}, \mathrm{BW}}$ was proposed by Bridges et al. (1986). Here BW is mid-BW $(\mathrm{kg})$ of the $\mathrm{i}^{\text {th }}$ pen, $\mathrm{C}$ is the average mature DFI, $\mathrm{ME}$, or NE intake, $\mathrm{M}$ is the exponential growth decay constant and $\mathrm{A}$ is the kinetic order constant. Since the exponential decay parameter was close to zero, the model was reparamaterized $\left.\left(\mathrm{M}^{\prime}=\log \mathrm{M}\right)\right)$ with the form, $\mathrm{DFI}_{\mathrm{i}, \mathrm{BW}}=$ $\mathrm{C}\left(1-\exp \left(-\exp \left(\mathrm{M}^{\prime}\right) \mathrm{BW}^{\mathrm{A}}\right)\right)$ (Craig and Schinckel, 2001; Schinckel et al., 2009b). In this function, the BW in which the rate in which daily feed, ME or NE intake changes from being increasing to decreasing relative to $\mathrm{BW}$ is called the inflection point (IP) and is equal to DFI times $\mathrm{F}$ where $\mathrm{F}=$ $1-\exp ((1 / \mathrm{A})-1)$. The age at the IP $=(\mathrm{A} \mathrm{M} /(\mathrm{A}-1))^{(-1 / \mathrm{A})}$. In this function, $\mathrm{C}, \mathrm{M}^{\prime}$ and $\mathrm{A}$ were considered as pen specific effects. After preliminary analyses were completed and no solution was obtained for the three random effects models, alternative analyses were completed using each equation. The alternative analyses predicted a random effect for $a_{i}$ as a linear function of $\mathrm{c}_{\mathrm{i}}\left(\mathrm{a}_{\mathrm{i}}=\mathrm{b} \mathrm{c}_{\mathrm{i}}\right)$ and $m_{i}^{\prime}$ as a linear function of $c_{i}$. In these analyses, the fixed parameter $A$ was replaced by $A+a_{i}\left(A+b_{i} c_{i}\right)$ or $M^{\prime}$ replaced by $M^{\prime}+b_{2} \quad c_{i}$. These analyses allowed for a pen specific value of $c_{i}$ to be predicted based upon a population wide linear relationship of the predicted random effect for $c_{i}$. The inclusion of the pen specific random effects into the Bridges function relating feed or energy intake to $\mathrm{BW}$ allows the prediction of pen specific feed and energy intake curves.

Feed efficiency (gain:feed) was predicted for each pig as the ratio of mean predicted DFI $(\mathrm{kg} / \mathrm{d})$ for each pen divided by the pen mean predicted ADG $(\mathrm{kg} / \mathrm{d})$ from the GMM function for each pig in the pen. The BW gain:ME intake above maintenance and BW gain:NE intake above maintenance were calculated using the predicted maintenance requirements of Noblet et al. (1999). The predicted DFIs, ME intakes, NE intakes and efficiency variables (gain:feed, gain:ME intake or gain:NE intake) at six BWs $(45,60,75,90,105$ and $120 \mathrm{~kg})$ were fitted to a model including the fixed effects of BW, replicate, sire line, diet, sex and their interactions using the MIXED procedure of SAS.

\section{RESULTS}

\section{Body weight growth}

The means and SDs for BW at each BW measurement are shown in Table 4. The SDs in age at the sixth, seventh, and final BW were greater than the other measurements as the timing of these final BWs were based upon each pig achieving its target BW.

The parameter estimates for the fitting of BW to the GMM function are shown in Table 5. The addition of random effects $\left(w f_{i}\right.$ and $k_{i}$ for barrows and $w_{i}$ and $c_{i}$ for gilts) increased the $\mathrm{R}^{2}$ values and reduced the residual standard deviations. Inclusion of the two random effects in the GMM function produces individual pig BW growth curves that differ in their shape (Schinckel et al., 2009a).

The least-squares means for the predicted ADGs for each sire line, sex and diet are shown in Table 6. The BWs and ADGs at 84,102,120, 138 and $156 \mathrm{~d}$ of age were affected $(\mathrm{p}<0.01)$ by sire line, sex and diet. There were also sire line by sex interactions $(\mathrm{p}<0.02)$ for ADG at 84,102 , and $120 \mathrm{~d}$ of age and overall. Pigs of sire line 3 had lower BWs and ADGs than pigs of the other three sire lines. Barrows of sire lines 1, 2 and 3 had 67,73 and $79 \mathrm{~g} / \mathrm{d}$ greater ADG than gilts versus line 4 barrows which only had $40 \mathrm{~g} / \mathrm{d}$ greater ADG than line 4 gilts Pigs fed the HE diets had $30 \mathrm{~g} / \mathrm{d}$ greater ADG than pigs fed the LE diets. The effect of the high energy diet on ADG was consistent from 84 to $156 \mathrm{~d}$ of age (diet by BW interaction, $\mathrm{p}=0.37$ ).

\section{Daily feed and energy intakes}

The parameters and statistics for fitting daily feed intake (DFI), daily ME intake and daily NE intake to BW are shown in Tables 7, 8 and 9. Addition of pen specific random effects to the Bridges function increased the $R^{2}$ and 
Table 4. Actual BW and SD and values predicted by the generalized Michaelis-Menten function at each time of measurement

\begin{tabular}{|c|c|c|c|c|c|c|c|}
\hline \multirow{2}{*}{$\begin{array}{l}\text { BW measurement } \\
\text { number }\end{array}$} & \multirow{2}{*}{$\mathrm{N}$} & \multicolumn{2}{|c|}{ Age } & \multicolumn{2}{|c|}{ Actual BW } & \multicolumn{2}{|c|}{ Predicted BW } \\
\hline & & Mean & SD & Mean & SD & Mean & SD \\
\hline \multicolumn{8}{|l|}{$\overline{\text { Gilts }}$} \\
\hline 1 & 2,186 & 50.4 & 4.6 & 16.80 & 4.29 & 16.31 & 3.43 \\
\hline 2 & 2,202 & 68.5 & 3.9 & 27.32 & 4.98 & 28.08 & 4.39 \\
\hline 3 & 2,192 & 99.1 & 2.7 & 53.04 & 6.94 & 53.15 & 6.58 \\
\hline 4 & 2,189 & 127.7 & 5.0 & 79.66 & 10.36 & 79.34 & 10.14 \\
\hline 5 & 2,178 & 157.1 & 4.4 & 105.72 & 12.45 & 106.07 & 11.73 \\
\hline 6 & 2,048 & 185.5 & 14.8 & 128.40 & 10.29 & 128.30 & 9.85 \\
\hline 7 & 36 & 192.8 & 12.9 & 124.61 & 10.04 & 123.89 & 9.17 \\
\hline Final $\mathrm{BW}^{\mathrm{a}}$ & 2,178 & 184.0 & 16.0 & 127.91 & 10.51 & 127.79 & 10.06 \\
\hline \multicolumn{8}{|l|}{ Barrows } \\
\hline 1 & 2,274 & 50.7 & 4.6 & 17.22 & 4.31 & 16.07 & 3.56 \\
\hline 2 & 2,288 & 68.6 & 3.8 & 27.61 & 5.16 & 28.34 & 4.78 \\
\hline 3 & 2,273 & 99.1 & 2.7 & 54.97 & 7.57 & 55.53 & 7.09 \\
\hline 4 & 2,261 & 127.7 & 5.2 & 84.97 & 11.02 & 84.29 & 10.67 \\
\hline 5 & 2,250 & 156.5 & 4.9 & 112.43 & 12.41 & 112.65 & 11.53 \\
\hline 6 & 1,941 & 180.0 & 13.2 & 131.75 & 10.05 & 131.79 & 9.60 \\
\hline 7 & 67 & 193.6 & 11.7 & 130.05 & 10.39 & 129.67 & 10.09 \\
\hline Final BW ${ }^{\mathrm{a}}$ & 2,250 & 176.9 & 15.6 & 130.36 & 10.72 & 130.43 & 10.24 \\
\hline
\end{tabular}

${ }^{\mathrm{a}}$ The final BW for all barrows and gilts with carcass weight data.

decreased the RSD values of the Bridges functions.

The sire line, sex, and diet least-squares means for DFI, daily ME intake, and daily NE intake are shown in Table 10. The main effects of sire line, sex, diet, BW $(45,60,75,90$,

Table 5. Parameters and statistics for the generalized MichaelisMenten function fitted to the BW data

\begin{tabular}{lcccc}
\hline & Estimate & SE & $\mathrm{R}^{2}$ & $\mathrm{RSD}(\mathrm{kg})$ \\
\hline Barrows & & & & \\
$\mathrm{WF}(\mathrm{kg})$ & 288.2 & 1.8 & 0.9977 & 2.07 \\
$\mathrm{~K}$ & 191.5 & 0.95 & & \\
$\mathrm{C}$ & 2.221 & 0.0051 & & \\
$\mathrm{~B}$ & 0.00264 & 0.00033 & & \\
$\operatorname{Var}\left(\mathrm{wf}_{\mathrm{i}}\right)$ & 1,357 & 82 & & \\
$\operatorname{Var}\left(\mathrm{k}_{\mathrm{i}}\right)$ & 276.6 & 23.8 & & \\
$\operatorname{Cov}\left(\mathrm{wf}_{\mathrm{ij}}, \mathrm{k}_{\mathrm{i}}\right)$ & 427 & 41 & & \\
$\operatorname{Var}\left(\mathrm{e}_{\mathrm{ij}}\right)$ & 6.11 & 0.10 & & \\
$\operatorname{Gilts}$ & & & & \\
$\mathrm{WF}, \mathrm{kg}$ & 300.4 & 2.0 & 0.9978 & 1.93 \\
$\mathrm{~K}$ & 211.1 & 1.2 & & \\
$\mathrm{C}$ & 2.077 & 0.0046 & \\
$\operatorname{Var}\left(\mathrm{wf}_{\mathrm{i}}\right)$ & 1,885 & 92.6 & \\
$\operatorname{Var}\left(\mathrm{k}_{\mathrm{i}}\right)$ & 486.5 & 28.5 & \\
$\operatorname{Cov}\left(\mathrm{wf}_{\mathrm{i}}, \mathrm{k}_{\mathrm{i}}\right)$ & 697 & 51.4 & \\
$\mathrm{~B}$ & 0.00086 & 0.00009 & \\
$\operatorname{Var}\left(\mathrm{e}_{\mathrm{i}, \mathrm{j}}\right)$ & 5.34 & 0.08 & \\
\hline
\end{tabular}

GMM has the form BW $=\mathrm{WT}_{0}+\left(\left(\mathrm{WF}-\mathrm{WT}_{0}\right)(\mathrm{t} / \mathrm{K})^{\mathrm{c}}\right) /\left(1+(\mathrm{t} / \mathrm{K})^{\mathrm{c}}\right)$ where $\mathrm{wf}_{\mathrm{t}}$ and $k_{i}$ and $c_{i}$ are random effects for $W F, k$ and $c$, respectively. $\mathrm{B}=$ Regression coefficient, $\mathrm{c}_{\mathrm{i}}=\mathrm{B}$ wf $\mathrm{f}_{\mathrm{i}}$ for gilts, $\mathrm{c}_{\mathrm{i}}=\mathrm{B} \mathrm{k}_{\mathrm{i}}$ for barrows.
105 and $120 \mathrm{~kg}$ ) were significant $(\mathrm{p}<0.001)$. Interactions of main effects with BW indicate that the shapes of the DFI curves are different. The sire line by BW, sex by BW and diet by BW interactions were significant $(p<0.001)$ for DFI. Pigs from line 3 sires had lower DFIs than pigs of the other sire lines and this difference increased with BW. Pigs from sire line 2 had slightly greater DFIs than sire lines 1 and 4 . The amount the DFIs of line 2 sired pigs were greater than line 1 and 4 pigs increased with BW (40 g/d at $45 \mathrm{~kg}$ to 120 $\mathrm{g} / \mathrm{d}$ at $105 \mathrm{~kg}$ and $135 \mathrm{~g} / \mathrm{d}$ at $120 \mathrm{~kg} \mathrm{BW})$. Barrows had $8.88 \%$ greater $(\mathrm{p}<0.05)$ DFI than gilts at $45 \mathrm{~kg} \mathrm{BW}$ which increased to $13.7 \%$ at $60 \mathrm{~kg}, 14.8 \%$ at $75 \mathrm{~kg}, 14.6 \%$ at 90 $\mathrm{kg}$ and then decreased to $12.6 \%$ at $105 \mathrm{~kg}$ and $11.1 \%$ at 120 $\mathrm{kg}$ BW. Pigs consumed $3.78 \%$ more of LE diet than the HE diet at $45 \mathrm{BW}$, which increased to $5.45 \%$ at $60 \mathrm{~kg}, 6.53 \%$ at $75 \mathrm{~kg}, 7.22 \%$ at $90 \mathrm{~kg} \mathrm{BW}, 8.00 \%$ at $105 \mathrm{~kg} \mathrm{BW}$ and $8.83 \%$ at $120 \mathrm{~kg} \mathrm{BW}$. The greater the $\mathrm{BW}$, the greater extent pigs consumed more of the LE diets relative to the HE diets.

The daily predicted ME and NE intakes were affected by sire line, sex and BW (45, 60, 75, 90, 105 and $120 \mathrm{~kg}$ ). Diet energy level (HE, LE) did not affect daily ME intake ( $p=0.49$ ) but did affect daily NE intake ( $p=0.01,6.33$ vs. $6.44 \mathrm{Mcal} / \mathrm{d}$ for LE and HE diets). Sire line by BW and sex by $B W$ interactions were significant $(p<0.001)$ for daily $\mathrm{ME}$ and NE intakes. Sire line 3 pigs had lower predicted daily $\mathrm{NE}$ and ME intakes than pigs from the other sire lines. The absolute and relative differences in $\mathrm{NE}$ and ME intakes between line 3 sired pigs and pigs by other sire lines increased as BW increased. The greater daily ME and NE 
Table 6. Least-squares means for BW and ADG as predicted from the generalized Michaelis-Menten function ${ }^{\mathrm{a}}$

\begin{tabular}{|c|c|c|c|c|c|c|c|c|c|c|c|}
\hline \multirow{2}{*}{ Variable } & \multicolumn{4}{|c|}{ Sire line } & \multirow{2}{*}{ SE } & \multicolumn{2}{|c|}{ Sex } & \multirow{2}{*}{ SE } & \multicolumn{2}{|c|}{ Diet } & \multirow{2}{*}{ SE } \\
\hline & 1 & 2 & 3 & 4 & & Barrows & Gilts & & High & Low & \\
\hline \multicolumn{12}{|l|}{$\mathrm{BW}(\mathrm{kg})$} \\
\hline 84-d & 40.2 & 42.3 & 39.4 & 40.8 & 0.97 & 41.2 & 40.1 & 0.88 & 41.2 & 40.1 & 0.88 \\
\hline $102-d$ & 56.6 & 59.2 & 54.8 & 57.1 & 0.97 & 58.2 & 55.6 & 0.88 & 57.7 & 56.1 & 0.88 \\
\hline $120-d$ & 74.1 & 77.0 & 71.1 & 74.5 & 0.97 & 76.2 & 72.1 & 0.88 & 75.2 & 73.1 & 0.88 \\
\hline $138-d$ & 92.0 & 94.9 & 87.3 & 92.1 & 0.97 & 94.4 & 88.7 & 0.88 & 92.9 & 90.3 & 0.88 \\
\hline $156-d$ & 109.5 & 112.4 & 103.1 & 109.2 & 0.97 & 112.1 & 105.1 & 0.88 & 110.1 & 107.0 & 0.88 \\
\hline \multicolumn{12}{|c|}{$\mathrm{ADG}(\mathrm{g} / \mathrm{d})$} \\
\hline $84-d$ & 861 & 891 & 818 & 862 & 12.2 & 893 & 822 & 12.4 & 871 & 844 & 12.4 \\
\hline $102-d$ & 947 & 970 & 886 & 943 & 12.2 & 979 & 894 & 12.4 & 951 & 922 & 12.4 \\
\hline $120-d$ & 987 & 1000 & 909 & 977 & 12.2 & 1,012 & 924 & 12.4 & 984 & 953 & 12.4 \\
\hline $138-d$ & 987 & 990 & 896 & 971 & 12.2 & 1,000 & 921 & 12.4 & 976 & 946 & 12.4 \\
\hline $156-d$ & 957 & 951 & 857 & 937 & 12.2 & 958 & 892 & 12.4 & 941 & 910 & 12.4 \\
\hline
\end{tabular}

${ }^{a}$ Sire line, sex and diet interactions are significant $(\mathrm{p}<0.001)$ at each age and overall. Sire line by diet and sex by diet interactions were not significant $(\mathrm{p}>0.05)$. Sire line by sex interactions were significant $(\mathrm{p}<0.01)$ for BW at all ages. Sire line by sex interactions were significant for ADG $(\mathrm{p}<0.05)$ at 84 , $102,120 \mathrm{~d}$ and overall. Overall sire line by age interactions and sex by age interactions are significant $(\mathrm{p}<0.001)$. Diet by age interaction was significant $(\mathrm{p}<0.001)$ for BW and not significant for ADG $(\mathrm{p}=0.37)$.

intakes of line 2 sired pigs in comparison to line 1 and 4 sired pigs increased with BW. Barrows had greater daily $\mathrm{ME}$ and NE intakes than gilts. The absolute difference between barrows and gilts for ME intake increased from $0.56 \mathrm{Mcal} / \mathrm{d}$ at $45 \mathrm{~kg} \mathrm{BW}$ to $1.02,1.23,1.26,1.20$ and 1.08 $\mathrm{Mcal} / \mathrm{d}$ at $60,75,90,105$, and $120 \mathrm{~kg} \mathrm{BW}$, respectively. The barrows had $0.40 \mathrm{Mcal}$ greater NE intakes than gilts at 45 $\mathrm{kg} \mathrm{BW}$ which increased to $0.72,0.88,0.92,0.87$, and 0.78 $\mathrm{Mcal} / \mathrm{d}$ at 60, 75, 90, 105 and $120 \mathrm{~kg} \mathrm{BW}$.

The overall sire line by sex and diet least-squares means for $\mathrm{ME}$ and $\mathrm{NE}$ energy intakes above maintenance are

Table 7. Parameters and statistics for Bridges Function fitted to daily feed intake $(\mathrm{kg} / \mathrm{d})^{\mathrm{a}}$

\begin{tabular}{|c|c|c|c|c|}
\hline Barrows & Estimate & SE & $\mathrm{R}^{2}$ & RSD \\
\hline$\overline{\mathrm{C}}$ & 3.235 & 0.035 & 0.942 & 0.140 \\
\hline$M^{\prime}$ & -5.089 & 0.128 & & \\
\hline A & 1.322 & 0.036 & & \\
\hline B1 & -0.08793 & 0.0064 & & \\
\hline $\operatorname{Var}\left(c_{i}\right)$ & 0.124 & 0.017 & & \\
\hline $\operatorname{Var}\left(e_{i, j}\right)$ & 0.0248 & 0.0014 & & \\
\hline \multicolumn{5}{|l|}{ Gilts } \\
\hline $\mathrm{C}$ & 3.256 & 0.098 & \multirow[t]{7}{*}{0.940} & \multirow[t]{7}{*}{0.120} \\
\hline $\mathrm{M}^{\prime}$ & -3.662 & 0.12 & & \\
\hline A & 0.9073 & 0.042 & & \\
\hline B1 & 0.1636 & 0.075 & & \\
\hline B2 & -0.8902 & 0.27 & & \\
\hline $\operatorname{Var}\left(c_{i}\right)$ & 0.1167 & 0.032 & & \\
\hline $\operatorname{Var}\left(e_{i, j}\right)$ & 0.0183 & 0.0011 & & \\
\hline $\begin{array}{l}\text { a Function } \\
\left(\mathrm{C}+\mathrm{c}_{\mathrm{i}}\right)(1-\mathrm{e} \\
\text { and } \mathrm{M}^{\prime} \text { are } \\
\mathrm{B} 2 \mathrm{c}_{\mathrm{i}} \text {, and a }\end{array}$ & the form & $\begin{array}{l}\mathrm{kg} / \mathrm{d})= \\
\text { where } \\
\text { is a rand }\end{array}$ & $\begin{array}{l}\text { exp(-e) } \\
\text { ympto }\end{array}$ & $\begin{array}{l}\text { BWA) or } \\
\text { intake, A, } \\
\text { pen, } \mathrm{m}^{\prime}=\end{array}$ \\
\hline
\end{tabular}

shown in Table 11. The daily ME and NE available for growth was estimated using the predicted maintenance requirements of Noblet et al. (1999) which was assumed to be appropriate for these genetic lines and diets. After accounting for maintenance, line 3 pigs had less energy available for growth, protein and lipid accretion, than pigs of the other sire lines. The line 3 gilts had the least daily $\mathrm{ME}$ and NE intakes above maintenance (4.07 and 2.15 $\mathrm{Mcal} / \mathrm{d}$, respectively) and line 2 barrows had the greatest overall daily ME and NE intakes above maintenance (5.83

Table 8. Parameters for the Bridges Function fitted to daily ME intake $(\mathrm{Mcal} / \mathrm{d})^{\mathrm{a}}$

\begin{tabular}{|c|c|c|c|c|}
\hline & Estimate & SE & $\overline{\mathrm{R}^{2}}$ & $\overline{R S D}$ \\
\hline \multicolumn{5}{|l|}{ Barrows } \\
\hline $\mathrm{C}$ & 11.00 & 0.115 & 0.942 & 0.475 \\
\hline $\mathrm{M}^{\prime}$ & -5.077 & 0.124 & & \\
\hline A & 1.320 & 0.035 & & \\
\hline B1 & -0.0321 & 0.0020 & & \\
\hline $\operatorname{Var}\left(c_{i}\right)$ & 1.178 & 0.174 & & \\
\hline $\operatorname{Var}\left(e_{i, j}\right)$ & 0.280 & 0.016 & & \\
\hline \multicolumn{5}{|l|}{ Gilts } \\
\hline $\mathrm{C}$ & 11.09 & 0.39 & 0.941 & 0.408 \\
\hline $\mathrm{M}^{\prime}$ & -3.666 & 0.12 & & \\
\hline A & 0.9089 & 0.042 & & \\
\hline B1 & 0.0268 & 0.014 & & \\
\hline B2 & -0.1964 & 0.057 & & \\
\hline $\operatorname{Var}\left(c_{i}\right)$ & 1.477 & 0.35 & & \\
\hline $\operatorname{Var}\left(\mathrm{e}_{\mathrm{i}, \mathrm{j}}\right)$ & 0.210 & 0.012 & & \\
\hline
\end{tabular}


Table 9. Parameters for the Bridges Function fitted to daily NE intake $(\mathrm{Mcal} / \mathrm{d})^{\mathrm{a}}$

\begin{tabular}{lclll}
\hline & Estimate & SE & $\mathrm{R}^{2}$ & RSD \\
\hline Barrows & & & & \\
$\mathrm{C}$ & 8.35 & 0.097 & 0.943 & 0.356 \\
$\mathrm{M}^{\prime}$ & -5.016 & 0.123 & & \\
$\mathrm{~A}$ & 1.287 & 0.034 & & \\
$\mathrm{~B} 1$ & -0.0406 & 0.0026 & & \\
$\operatorname{Var}\left(\mathrm{c}_{\mathrm{i}}\right)$ & 0.723 & 0.109 & & \\
$\operatorname{Var}\left(\mathrm{e}_{\mathrm{i}, \mathrm{j}}\right)$ & 0.158 & 0.009 & & \\
Gilts & & & & \\
$\mathrm{C}$ & 8.71 & 0.34 & 0.942 & 0.306 \\
$\mathrm{M}^{\prime}$ & -3.684 & 0.11 & & \\
$\mathrm{~A}$ & 0.8851 & 0.042 & & \\
$\mathrm{~B} 1$ & 0.0332 & 0.016 & & \\
$\mathrm{~B} 2$ & -0.1398 & 0.066 & & \\
$\operatorname{Var}\left(\mathrm{c}_{\mathrm{i}}\right)$ & 0.943 & 0.23 & & \\
$\operatorname{Var}\left(\mathrm{e}_{\mathrm{i}, \mathrm{j}}\right)$ & 0.118 & 0.007 & & \\
\hline
\end{tabular}

${ }^{a}$ Function has the form NE intake $(\mathrm{Mcal} / \mathrm{d})=\mathrm{C}\left(1-\exp \left(-\exp \left(\mathrm{M}^{\prime}\right) \mathrm{BW}^{\mathrm{A}}\right)\right.$ or $\left(C+c_{i}\right)\left(1-\exp \left(-\exp \left(M^{\prime}+m^{\prime}\right) B W^{\left(A+a_{i}\right)}\right.\right.$ where $C$ is asymptotic NE intake, $A$, and $\mathrm{M}^{\prime}$ are function parameters, $\mathrm{c}_{\mathrm{i}}$ is a random effect for the ith pen, $\mathrm{m}^{\prime}=$ $\mathrm{B} 2 \mathrm{c}_{\mathrm{i}}$, and $\mathrm{a}_{\mathrm{i}}=\mathrm{B} 1 \mathrm{c}$.

and $3.45 \mathrm{~kg} / \mathrm{d}$ ). These represent 43.2 and $60.5 \%$ differences in energy available for protein and lipid accretion.

\section{Measures of feed and energetic efficiency}

The least-squares means for the predicted feed and energy efficiency variables are shown in Table 12. Predicted gain:feed was affected $(\mathrm{p}<0.001)$ by sire line, diet, sex, BW, sire line by BW, sex by BW, and diet by BW. The sire line by sex interaction was not significant $(p=0.071)$ for gain:feed. The sire line by BW, sex by BW and diet by BW interactions indicate that the absolute differences in gain:feed differed with BW. Overall, the differences in gain:feed were small at 45, 60 and $75 \mathrm{~kg} \mathrm{BW}$. The sire line differences became more apparent at $90 \mathrm{~kg} \mathrm{BW}$ and increased at 105 and $120 \mathrm{~kg} \mathrm{BW}$. Pigs from sire line $1 \mathrm{had}$ greater $(\mathrm{p}<0.05)$ gain:feed than the pigs by the other sire lines at 90, 105 and $120 \mathrm{~kg}$ BW. Barrows and gilts had similar gain:feed at $45 \mathrm{~kg}$ BW (0.469 and 0.473, respectively). Gilts had greater gain:feed than barrows after $60 \mathrm{~kg} \mathrm{BW}$. The gilt advantage in gain:feed was fairly consistent $(0.012$ to $0.019,3.7$ to $5.0 \%$ ) from 60 to $120 \mathrm{~kg}$ BW.

Pigs fed the HE diets had $9.64 \%$ greater $(p<0.001)$ gain:feed than pigs fed the LE diets. The absolute differences in gain:feed for pigs fed the HE and LE diets were $0.029,0.032,0.035,0.038,0.038$, and 0.038 at 45,60 , $75,90,105$ and $120 \mathrm{~kg} \mathrm{BW}$. The percentage advantage in gain:feed for pigs fed HE diets in comparison to pigs fed the LE diets increased as BW increased (6.3, 7.9, 9.5, 11.3, 12.1 and $13.0 \%$ at $45,60,75,90,105$ and $120 \mathrm{~kg} \mathrm{BW}$, respectively).

The values for gain:ME intake or gain:NE intake were both affected $(\mathrm{p}<0.01)$ the main effects by sire line, sex, sire

Table 10. Least-squares means for predicted daily feed intake, ME and NE intake at six BWs ${ }^{\mathrm{a}}$

\begin{tabular}{|c|c|c|c|c|c|c|c|c|c|c|c|}
\hline \multirow{2}{*}{ DFI (kg/d) } & \multicolumn{5}{|c|}{ Sire line } & \multicolumn{3}{|c|}{ Sex } & \multicolumn{3}{|c|}{ Diet } \\
\hline & 1 & 2 & 3 & 4 & SE & Barrow & Gilt & SE & High & Low & SE \\
\hline $45 \mathrm{~kg}$ & 1.89 & 1.93 & 1.82 & 1.89 & 0.039 & 1.96 & 1.80 & 0.036 & 1.85 & 1.92 & 0.036 \\
\hline $60 \mathrm{~kg}$ & 2.27 & 2.33 & 2.17 & 2.27 & 0.039 & 2.40 & 2.11 & 0.036 & 2.20 & 2.32 & 0.036 \\
\hline $75 \mathrm{~kg}$ & 2.54 & 2.63 & 2.41 & 2.55 & 0.039 & 2.71 & 2.36 & 0.036 & 2.45 & 2.61 & 0.036 \\
\hline $90 \mathrm{~kg}$ & 2.74 & 2.84 & 2.57 & 2.75 & 0.039 & 2.91 & 2.54 & 0.036 & 2.63 & 2.82 & 0.036 \\
\hline $105 \mathrm{~kg}$ & 2.88 & 3.00 & 2.69 & 2.88 & 0.039 & 3.03 & 2.69 & 0.036 & 2.75 & 2.97 & 0.036 \\
\hline $120 \mathrm{~kg}$ & 2.97 & 3.11 & 2.76 & 2.98 & 0.039 & 3.11 & 2.80 & 0.036 & 2.83 & 3.08 & 0.036 \\
\hline \multicolumn{12}{|c|}{ Daily ME intake (Mcal/d) } \\
\hline $45 \mathrm{~kg}$ & 6.55 & 6.64 & 6.37 & 6.56 & 0.12 & 6.81 & 6.25 & 0.11 & 6.54 & 6.51 & 0.11 \\
\hline $60 \mathrm{~kg}$ & 7.86 & 8.03 & 7.54 & 7.88 & 0.12 & 8.33 & 7.31 & 0.11 & 7.83 & 7.83 & 0.11 \\
\hline $75 \mathrm{~kg}$ & 8.82 & 9.06 & 8.36 & 8.83 & 0.12 & 9.38 & 8.16 & 0.11 & 8.76 & 8.78 & 0.11 \\
\hline $90 \mathrm{~kg}$ & 9.48 & 9.80 & 8.90 & 9.50 & 0.12 & 10.05 & 8.79 & 0.11 & 9.41 & 9.44 & 0.11 \\
\hline $105 \mathrm{~kg}$ & 9.92 & 10.31 & 9.27 & 9.96 & 0.12 & 10.47 & 9.27 & 0.11 & 9.84 & 9.88 & 0.11 \\
\hline $120 \mathrm{~kg}$ & 10.24 & 10.67 & 9.49 & 10.26 & 0.12 & 10.70 & 9.62 & 0.11 & 10.13 & 10.19 & 0.11 \\
\hline \multicolumn{12}{|c|}{ Daily NE intake } \\
\hline $45 \mathrm{~kg}$ & 4.70 & 4.77 & 4.56 & 4.71 & 0.091 & 4.88 & 4.48 & 0.087 & 4.70 & 4.67 & 0.087 \\
\hline $60 \mathrm{~kg}$ & 5.67 & 5.78 & 5.43 & 5.66 & 0.091 & 5.99 & 5.28 & 0.087 & 5.65 & 5.62 & 0.087 \\
\hline $75 \mathrm{~kg}$ & 6.39 & 6.5 & 6.069 & 6.39 & 0.091 & 6.79 & 5.91 & 0.087 & 6.37 & 6.33 & 0.087 \\
\hline $90 \mathrm{~kg}$ & 6.92 & 7.14 & 6.51 & 6.93 & 0.091 & 7.33 & 6.41 & 0.087 & 6.90 & 6.85 & 0.087 \\
\hline $105 \mathrm{~kg}$ & 7.31 & 7.58 & 6.83 & 7.32 & 0.091 & 7.69 & 6.82 & 0.087 & 7.34 & 7.23 & 0.087 \\
\hline $120 \mathrm{~kg}$ & 7.58 & 7.90 & 7.04 & 7.61 & 0.091 & 7.92 & 7.14 & 0.087 & 7.56 & 7.50 & 0.087 \\
\hline
\end{tabular}

${ }^{\mathrm{a}}$ Effects of sire line (SL), sex (S), diet (D), BW, SL $\times \mathrm{BW}, \mathrm{S} \times \mathrm{BW}$ and $\mathrm{D} \times \mathrm{BW}$ were significant (p<0.001) for DFI. Effects of SL, S, BW, SL $\times \mathrm{BW}$, and $\mathrm{S} \times \mathrm{BW}(\mathrm{p}<0.001)$ were significant for daily ME and NE intake. Diet was significant $(\mathrm{p}<0.01)$ for daily NE intake. 
Table 11. Sire line by sex and diet least-squares means for daily feed intake, daily ME intake and daily ME intake above maintenance.

\begin{tabular}{llccccc}
\hline \multirow{2}{*}{ Sire line } & Sex & \multicolumn{2}{c}{$\begin{array}{c}\text { ME Intake above } \\
\text { maintenance } \\
(\text { Mcal/d) }\end{array}$} & & \multicolumn{2}{c}{$\begin{array}{c}\text { NE Intake above } \\
\text { maintenance } \\
\text { (Mcal/d) }\end{array}$} \\
\cline { 3 - 4 } \cline { 6 - 7 } & & Mean & SE & & Mean & SE \\
\hline 1 & Barrow & 5.57 & 0.12 & & 3.23 & 0.09 \\
1 & Gilt & 4.58 & 0.12 & & 2.50 & 0.09 \\
2 & Barrow & 5.83 & 0.12 & & 3.42 & 0.09 \\
2 & Gilt & 4.87 & 0.12 & & 2.71 & 0.09 \\
3 & Barrow & 5.14 & 0.12 & & 2.91 & 0.09 \\
3 & Gilt & 4.08 & 0.12 & & 2.12 & 0.09 \\
4 & Barrow & 5.63 & 0.12 & & 3.29 & 0.09 \\
4 & Gilt & 4.56 & 0.12 & & 2.49 & 0.09 \\
Diet & & & & & \\
High energy & & 5.02 & 0.11 & & 2.86 & 0.08 \\
Low energy & & 5.05 & 0.11 & & 2.82 & 0.08 \\
\hline
\end{tabular}

${ }^{a}$ Mean predicted values at 45, 60, 75, 90, 105 and $120 \mathrm{~kg} \mathrm{BW}$. Effects of $\mathrm{SL}, \mathrm{S}, \mathrm{BW}, \mathrm{SL} \times \mathrm{BW}$, and $\mathrm{S} \times \mathrm{BW}(\mathrm{p}<0.001)$ were significant for daily $\mathrm{ME}$ and NE intake above maintenance. The $\mathrm{SL} \times \mathrm{S}$ and $\mathrm{SL} \times \mathrm{D}$ interactions were not significant $(\mathrm{p}>0.30)$.

line by sex, BW, and sire line by BW and sex by BW interactions. Diet affected the gain:ME intake ratio $(\mathrm{p}<$ $0.01)$ but not gain:NE intake values $(\mathrm{p}=0.23)$. The sire line differences in gain:ME and gain:NE intakes increased as BW increased. Pigs from sire line 4 had greater gain:ME and NE intake than pigs from sire lines 2 and 3 at 75, 90, 105 and $120 \mathrm{~kg} \mathrm{BW}$. Barrows and gilts had similar predicted gain:ME or NE intake at $45 \mathrm{~kg}$ BW. After $60 \mathrm{~kg}$ $\mathrm{BW}$, gilts had 3 to $5 \%$ greater gain:ME or NE intake than barrows. The greatest percentage advantage for gilts was 5.2\% for gain:ME and 5.0\% for gain:NE at $75 \mathrm{~kg} \mathrm{BW.} \mathrm{Pigs}$ fed the high HE diets had $3.27 \%$ greater gain:ME intake and $2.36 \%$ greater gain:NE intake than pigs fed the LE diet. The effect of diet was similar for gain:ME and for gain:NE intake from 45 to $120 \mathrm{~kg} \mathrm{BW}$.

Predicted BW gain:ME intake above maintenance was affected $(p<0.01)$ by the main effects of sire line, sex, diet and $\mathrm{BW}$ and interactions of sire line by sex, sire line by BW and sex by BW. At $45 \mathrm{~kg} \mathrm{BW}$, pigs from the four sire lines had identical gain:ME intake above maintenance. As BW increased, the predicted BW gain:ME intake above maintenance decreased more rapidly for sire line 2 pigs $(0.227$ at $45 \mathrm{~kg}$ to 0.158 at $120 \mathrm{~kg} \mathrm{BW} \mathrm{kg} / \mathrm{Mcal})$ than pigs of the other sire lines $(0.227$ to $0.173 \mathrm{~kg} / \mathrm{Mcal}$ at 45 and 120 $\mathrm{kg} \mathrm{BW}$ ). Pigs from sire line 1 and 3 had slightly greater predicted gain:ME intake above maintenance than pigs sired from line 4.

Gilts had greater gain:ME intake above maintenance than barrows at all BWs. Gilts had $6.8 \%$ greater predicted gain:ME intake above maintenance than barrows at 45 $\mathrm{kg} \mathrm{BW}$. From 60 to $120 \mathrm{~kg} \mathrm{BW}$, gilts had 14 to $16 \%$ greater predicted gain:ME intake above maintenance than barrows. The differences in predicted gain:ME intake above maintenance between barrows and gilts differed by sire line ( $\mathrm{p}=0.0031 ; 0.0257,0.0197,0.0293$, and $0.0286 \mathrm{~kg} / \mathrm{Mcal}$ for sire lines 1 through 4 , respectively).

Predicted gain:NE intake above maintenance was affected by the main effects of sire line, sex and BW and interactions of sire line by BW and sex by BW. Pigs from the four sire lines had similar gain:NE intake above maintenance at $45 \mathrm{~kg} \mathrm{BW}$. The difference in gain:NE intake above maintenance between pigs of the four sire lines increased as BW increased. Gilts had $6.25 \%$ greater predicted gain:NE intake above maintenance than barrows at $45 \mathrm{~kg} \mathrm{BW}$ which increased to a range of 12.0 to $14.5 \%$ from 60 to $120 \mathrm{~kg} \mathrm{BW}$. The differences in gain:NE intake above maintenance between the sexes differed $(p=0.005)$ amongst the pigs of the four sire lines. The gilts' advantage relative to barrows for gain:NE intake above maintenance were $0.0290,0.0220,0.0322$ and 0.0252 for sire lines 1 through 4 .

\section{DISCUSSION}

The addition of pig specific random effects to the solution of the GMM function describing the relationship of BW to days of age increased the estimates of WF (mature $\mathrm{BW}$ ) and $\mathrm{K}$. The termination of pig BW data at specific target BWs produces biased estimates of WF and predicted ADGs at heavier BWs (Schinckel and de Lange, 1996; Craig and Schinckel, 2001; Schinckel et al., 2009a). The addition of the pig specific random effects reduces the standard errors of the GMM parameters and reduces the bias produced by the target BW data endpoints.

The BW growth curves are affected by the pigs' genetic potential, nutrition and environmental stressors including health status, stocking density and heat stress (Schinckel and de Lange, 1996; Hamilton et al., 2003). The pigs in this trial were provided $0.635 \mathrm{~m}^{2}$ per pig to reflect commercial conditions. The floor space allowance required for maximum growth is a function of $\mathrm{K}$ times $\mathrm{BW}^{0.667}$ (Gonyou et al., 2006). Based upon the $K$ values of Gonyou et al. (2006), the pigs' ADG was reduced by the $0.635 \mathrm{~m}^{2}$ stocking density at 89 to $102 \mathrm{~kg} \mathrm{BW}$. At heavier BWs, as the fastest gaining pigs reached their target BWs, the ADG of the remaining pigs likely increased in comparison to if no pigs were removed (DeDecker et al., 2005).

There were significant sire line by sex interactions for ADG from 84 to $120 \mathrm{~d}$ of age and predicted maximum ADG. In this trial, sire line by sex interactions were not significant for daily feed, ME or NE intake. All measures of gain per unit energy intake were affected by sire line by sex interactions. Other researchers have found genetic 
population by sex interactions (Schinckel and de Lange, diets grew 3.2\% slower.

1996). These interactions require evaluation of barrows and gilts of each genetic population. Swine growth models require genetic population-sex specific parameters for energy intake and compositional growth rates (de Lange and Schreurs, 1995; Schinckel and de Lange, 1996).

Overall, pigs fed the LE diets had $6.9 \%$ greater daily feed intakes and nearly identical ME and NE intakes as pigs fed the HE diets (99.8 and $99.4 \%$, respectively). Although $\mathrm{ME}$ and NE intakes were nearly identical, pigs fed the LE

The addition of fat to pig diets almost always increases gain:feed and reduces ADFI (Pettigrew and Moser, 1991; Weber et al., 2006; De la Llata et al., 2007). The relative increases in ADG and daily ME intakes by feeding diets with added fat are variable (Pettigrew and Moser, 1991) and may be affected by the BW range (De la Llata et al., 2001; 2007).

The advantage of the HE diets were 3.50, 3.36, 1.33 and $0.11 \%$ for gain:MEI, gain:MEI above maintenance, gain:NE

Table 12. Least-squares means for predicted gain:feed $(\mathrm{kg} / \mathrm{kg})$, gain:ME intake $(\mathrm{kg} / \mathrm{Mcal})$ and gain:ME intake above maintenance $(\mathrm{kg} / \mathrm{Mcal})$ at six BWs ${ }^{\mathrm{a}}$

\begin{tabular}{|c|c|c|c|c|c|c|c|c|c|c|c|}
\hline \multirow{2}{*}{ Gain:feed } & \multicolumn{5}{|c|}{ Sire line } & \multicolumn{3}{|c|}{ Sex } & \multicolumn{3}{|c|}{ Diet } \\
\hline & 1 & 2 & 3 & 4 & $\mathrm{SE}$ & Barrow & Gilt & SE & High & Low & SE \\
\hline $45 \mathrm{~kg}$ & 0.474 & 0.473 & 0.467 & 0.471 & 0.0033 & 0.469 & 0.473 & 0.0031 & 0.486 & 0.457 & 0.0031 \\
\hline $60 \mathrm{~kg}$ & 0.426 & 0.420 & 0.417 & 0.421 & 0.0033 & 0.412 & 0.430 & 0.0031 & 0.437 & 0.405 & 0.0031 \\
\hline $75 \mathrm{~kg}$ & 0.392 & 0.383 & 0.380 & 0.386 & 0.0033 & 0.376 & 0.395 & 0.0031 & 0.403 & 0.368 & 0.0031 \\
\hline $90 \mathrm{~kg}$ & 0.365 & 0.353 & 0.349 & 0.358 & 0.0033 & 0.348 & 0.364 & 0.0031 & 0.375 & 0.337 & 0.0031 \\
\hline $105 \mathrm{~kg}$ & 0.340 & 0.327 & 0.323 & 0.333 & 0.0033 & 0.325 & 0.337 & 0.0031 & 0.350 & 0.312 & 0.0031 \\
\hline $120 \mathrm{~kg}$ & 0.321 & 0.306 & 0.308 & 0.314 & 0.0033 & 0.306 & 0.318 & 0.0031 & 0.331 & 0.293 & 0.0031 \\
\hline \multicolumn{12}{|c|}{ Gain:ME (kg/Mcal) } \\
\hline $45 \mathrm{~kg}$ & 0.139 & 0.140 & 0.136 & 0.138 & 0.0009 & 0.138 & 0.139 & 0.0008 & 0.140 & 0.135 & 0.0008 \\
\hline $60 \mathrm{~kg}$ & 0.125 & 0.124 & 0.122 & 0.124 & 0.0009 & 0.121 & 0.126 & 0.0008 & 0.125 & 0.122 & 0.0008 \\
\hline $75 \mathrm{~kg}$ & 0.115 & 0.113 & 0.111 & 0.113 & 0.0009 & 0.110 & 0.116 & 0.0008 & 0.115 & 0.111 & 0.0008 \\
\hline $90 \mathrm{~kg}$ & 0.107 & 0.104 & 0.102 & 0.105 & 0.0009 & 0.102 & 0.107 & 0.0008 & 0.107 & 0.103 & 0.0008 \\
\hline $105 \mathrm{~kg}$ & 0.100 & 0.096 & 0.095 & 0.098 & 0.0009 & 0.095 & 0.100 & 0.0008 & 0.099 & 0.095 & 0.0008 \\
\hline $120 \mathrm{~kg}$ & 0.094 & 0.090 & 0.091 & 0.092 & 0.0009 & 0.090 & 0.093 & 0.0008 & 0.094 & 0.090 & 0.0008 \\
\hline \multicolumn{12}{|c|}{ Gain: ME above maintenance } \\
\hline $45 \mathrm{~kg}$ & 0.228 & 0.227 & 0.228 & 0.227 & 0.0031 & 0.220 & 0.225 & 0.0029 & 0.231 & 0.225 & 0.0029 \\
\hline $60 \mathrm{~kg}$ & 0.205 & 0.200 & 0.205 & 0.202 & 0.0031 & 0.190 & 0.216 & 0.0029 & 0.206 & 0.200 & 0.0029 \\
\hline $75 \mathrm{~kg}$ & 0.191 & 0.184 & 0.192 & 0.188 & 0.0031 & 0.175 & 0.203 & 0.0029 & 0.193 & 0.186 & 0.0029 \\
\hline $90 \mathrm{~kg}$ & 0.182 & 0.173 & 0.183 & 0.179 & 0.0031 & 0.167 & 0.192 & 0.0029 & 0.183 & 0.176 & 0.0029 \\
\hline $105 \mathrm{~kg}$ & 0.176 & 0.164 & 0.178 & 0.172 & 0.0031 & 0.161 & 0.184 & 0.0029 & 0.177 & 0.168 & 0.0029 \\
\hline $120 \mathrm{~kg}$ & 0.172 & 0.158 & 0.173 & 0.168 & 0.0031 & 0.158 & 0.180 & 0.0029 & 0.173 & 0.165 & 0.0029 \\
\hline \multicolumn{12}{|c|}{ Gain:NE intake } \\
\hline $45 \mathrm{~kg}$ & 0.1897 & 0.1904 & 0.1835 & 0.1885 & 0.0012 & 0.1878 & 0.1893 & 0.0012 & 0.1903 & 0.1886 & 0.0012 \\
\hline $60 \mathrm{~kg}$ & 0.1636 & 0.1685 & 0.1649 & 0.1679 & 0.0012 & 0.1641 & 0.1713 & 0.0012 & 0.1695 & 0.1677 & 0.0012 \\
\hline $75 \mathrm{~kg}$ & 0.1553 & 0.1527 & 0.1497 & 0.1530 & 0.0012 & 0.1489 & 0.1564 & 0.0012 & 0.1545 & 0.1524 & 0.0012 \\
\hline $90 \mathrm{~kg}$ & 0.1453 & 0.1398 & 0.1369 & 0.1408 & 0.0012 & 0.1373 & 0.1432 & 0.0012 & 0.1421 & 0.1398 & 0.0012 \\
\hline $105 \mathrm{~kg}$ & 0.1333 & 0.1286 & 0.1263 & 0.1303 & 0.0012 & 0.1274 & 0.1318 & 0.0012 & 0.1314 & 0.1292 & 0.0012 \\
\hline $120 \mathrm{~kg}$ & 0.1250 & 0.1193 & 0.1199 & 0.1222 & 0.0012 & 0.1195 & 0.1238 & 0.0012 & 0.1233 & 0.1212 & 0.0012 \\
\hline \multicolumn{12}{|c|}{ Gain:NE intake above maintenance } \\
\hline $45 \mathrm{~kg}$ & 0.3029 & 0.3013 & 0.3022 & 0.3008 & 0.0036 & 0.2926 & 0.3109 & 0.0034 & 0.3042 & 0.3040 & 0.0034 \\
\hline $60 \mathrm{~kg}$ & 0.2695 & 0.2641 & 0.2694 & 0.2665 & 0.0036 & 0.2514 & 0.2833 & 0.0034 & 0.2696 & 0.2695 & 0.0034 \\
\hline $75 \mathrm{~kg}$ & 0.2494 & 0.2408 & 0.2489 & 0.2454 & 0.0036 & 0.2295 & 0.2628 & 0.0034 & 0.2484 & 0.2478 & 0.0034 \\
\hline $90 \mathrm{~kg}$ & 0.2349 & 0.2238 & 0.2338 & 0.2301 & 0.0036 & 0.2158 & 0.2455 & 0.0034 & 0.2330 & 0.2319 & 0.0034 \\
\hline $105 \mathrm{~kg}$ & 0.2236 & 0.2102 & 0.2231 & 0.2183 & 0.0036 & 0.2059 & 0.2317 & 0.0034 & 0.2209 & 0.2200 & 0.0034 \\
\hline $120 \mathrm{~kg}$ & 0.2160 & 0.2000 & 0.2203 & 0.2108 & 0.0036 & 0.1998 & 0.2238 & 0.0034 & 0.2136 & 0.2130 & 0.0034 \\
\hline
\end{tabular}

${ }^{a}$ Gain:feed was effected $(\mathrm{p}<0.001)$ by sire line $(\mathrm{SL})$, sex $(\mathrm{S})$, diet $(\mathrm{D}), \mathrm{BW}, \mathrm{SL} \times \mathrm{BW}, \mathrm{S} \times \mathrm{BW}$ and $\mathrm{D} \times \mathrm{BW}$. Gain:ME intake and Gain:ME above maintenance were affected $(\mathrm{p}<0.01)$ by $\mathrm{SL}, \mathrm{S}, \mathrm{SL} \times \mathrm{S}, \mathrm{D}, \mathrm{BW}, \mathrm{SL} \times \mathrm{BW}$ and $\mathrm{S} \times \mathrm{BW}$. Gain:NE intake above $\mathrm{M}$ was affected $(\mathrm{p}<0.01)$ by $\mathrm{SL}, \mathrm{S}, \mathrm{SL} \times \mathrm{S}, \mathrm{BW}, \mathrm{SL} \times \mathrm{BW}$ and $\mathrm{S} \times \mathrm{BW}$. 
intake, and gain:NE intake above maintenance, respectively (Table 12). The fact that the dietary differences in gain are less for NE than ME indicates that NE intake is a better predictor of pig BW gain than DFI or ME intake. The advantages of NE systems have been discussed (Noblet, 2000; Noblet and van Milgen, 2004). Other researchers likewise have shown that dietary differences in gain:NE are less than those observed for gain:ME (De la Llata et al., 2001; Noblet and van Milgen, 2004).

Gilts had greater BW gain:NE above maintenance than barrows. Gilts are expected to have greater BW gain per unit NE intake above maintenance as gilts have greater ratio of protein accretion relative to lipid accretion (Noblet et al., 1999; Schinckel et al., 2008). Genetic selection for increased muscle growth and decreased fat tissue growth has reduced the amount of dietary energy required per kilogram of BW gain (Schinckel and De Lange, 1996).

Pigs fed the HE diets had $0.11 \%$ greater BW gain:NE intake above maintenance than pigs fed the LE diets. The pigs fed the HE diets had $5.4 \%$ greater backfat depth and $0.80 \%$ less predicted fat-free lean percentage (50.8 vs. $51.6 \%)$. Other researchers have found that the addition of fat to swine diets increased backfat depth and reduced predicted carcass lean percentage (Pettigrew and Moser, 1991; La Llata et al., 2001; Weber et al., 2006).

With increased carcass leanness, it is expected the gain:NE intake above maintenance should be greater for pigs fed the LE diet. For example, gilts which had $4.02 \mathrm{~mm}$ less backfat depth and $3.3 \%$ greater fat-free lean percentage (52.9 vs. $49.6 \%$ fat-free lean, Schinckel et al., 2012) had approximately $13 \%$ greater gain:NE intake above maintenance. Based on the backfat differences between pigs fed the HE and LE diets (19.4 vs. $18.4 \mathrm{~mm}$ ), pigs fed the LE diets should have approximately $3.2 \%$ greater gain:NE intake above maintenance than pigs fed the HE diets. Most likely the maintenance requirement is greater for pigs fed the LE diets. Feeding of LE diets with increased fiber concentrations can increase the amount of endogenous gut losses (Mariscal-Landin et al., 1995; Nyachoti et al., 1996). Perhaps more importantly, it is also possible that viscera organ mass increased with the feeding of the LE diets. Viscera mass has approximately three times greater maintenance requirement per $\mathrm{kg}^{0.70}$ than muscle mass (Noblet et al., 1999). Pigs fed the HE diets had both greater dietary lipid intake and lipid accretion. The HE, high fat diets may have an advantage in that the direct deposition of dietary fat to lipid accretion is an energetically efficient process (about 90\%; Whittemore, 1997; Birkett et al., 2001c; Noblet and Milgen, 2004). Nutrient flow models which consider the animals' ultimate use of the nutrients (protein, starch, fat) and the increased endogenous secretions produced by some feedstuffs and their impact on maintenance requirements could better account for the differences in pig performance observed in this trial (Birkett and de Lange, 2001a, b).

\section{IMPLICATIONS}

A method to validate diet energy value (ME, NE) using growth assay and modeling technique was demonstrated using LE and HE diets. NE proved to be a more accurate descriptor in each case. Pigs fed the LE diets had greater daily feed intakes but equal daily $\mathrm{NE}$ and $\mathrm{ME}$ intakes compared to pigs fed the HE diets. Pigs fed the LE diets grew more slowly, had less backfat and greater predicted percent lean than pigs fed the HE diets. The effects of the LE versus HE diets were consistent across the genetic lines used in this trial. The results suggest that pigs fed LE diets may have greater daily maintenance requirements for energy than pigs fed HE energy diets and that NE is a better predictor of pig growth than ME. This is remarkably illustrated using both genders and four sire lines.

\section{REFERENCES}

Birkett, S. and K. de Lange. 2001a. A computational framework for a nutrient flow representation of energy utilization by growing monogastric animals. Br. J. Nutr. 86:661-674.

Birkett, S. an K. de Lange. 2001b. Calibration of a nutrient flow model of energy utilization by growing pigs. Br. J. Nutr. 96: 675-689.

Boyd, R. D., C. E. Zier-Rush.and C. E. Fralick. 2011. Practical method for productive energy $(\mathrm{NEm}+\mathrm{g})$ estimation of soybean meal for growing pigs. J. Anim. Sci. (abstr., in press).

Boyd, R. D., C. E. Zier-Rush and C. E. Fralick. 2010. Practical method for estimating productive energy (NE) of wheat midds for growing pigs. J. Anim. Sci. 88(E Suppl. 3):89(abstr.).

Bridges, T. C., U. W. Turner, E. M. Smith, T. S. Stahly and O. J. Loewer. 1986. A mathematical procedure for estimating animal growth and body composition. Trans. Am. Soc. Agric. Biol. Eng. 29:1342-1347.

Craig, B. A. and A. P. Schinckel. 2001. Nonlinear mixed effects model for swine growth. Prof. Anim. Sci. 17:256-260.

DeDecker, J. M., M. Ellis, B. F. Wolter, B. P. Corrigan, S. E. Curtis, E. N. Parr and D. M. Webel. 2005. Effects of proportion of pigs removed from a group and subsequent floor space on growth performance of finishing pigs. J. Anim. Sci. 83:449454.

De la Llata, M., S. S. Dritz, M. D. Tokach, R. D. Goodband, J. L. Nelssen and T. M. Loughin. 2001. Effects of dietary fat on growth performance and carcass characteristics of growingfinishing pigs reared in a commercial environment. J. Anim. Sci. 79:2643-2650.

De la Llata, M., S. S. Dritz, M. D. Tokach, R. D. Goodband and L. L. Nelssen. 2007. Effects of increasing lysine to calorie ratio and added fat for growing-finishing pigs reared in a commercial environment: I. Growth performance and carcass characteristics. Professional Animal Scientist 23:417-428.

de Lange, C. F. M. and H. W. E. Schreurs. 1995. Principles of model application. In Modelling Growth in the Pig, EAAP 
publication. 78:187-208

FASS. 2010. Guide for the care and use of agricultural animals in research and teaching. Third edition. Fed. Anim. Sci. Soc. Champaign, IL.

Gonyou, H. W., M. C. Brumm, E. Bush, J. Deen, S. A. Edwards, T. Fangman, J. J. McGlone, M. Meunier-Salaun, R. B. Morrison, H. Spoolder, P. L. Sundberg and A. K. Johnson. 2006. Application of broken-line analysis to assess floor space requirements of nursery and grower-finisher pigs expressed on an allometric basis. J. Anim. Sci. 84:229-235.

Hamilton, D. N., M. Ellis, B. F. Wolter, A. P. Schinckel and E. R. Wilson. 2003. The growth performance of the progeny of two swine sire lines reared under different floor space allowances. J. Anim. Sci. 81:1126-1135.

Krick, B. J. , K. R. Roneker, R. D. Boyd, D. H. Beermann, P. J. David and D. J. Meisinger. 1992. Influence of genotype and sex on the response of growing pigs to recombinant porcine somatotropin. J. Anim. Sci. 70:3024-3034.

Lopez, S., J. France, W. J. J. Gerrits, M. S. Dhanoa, D. J. Humphries and J. Dijkstra. 2000. A generalized MichaelisMenten equation for the analysis of growth. J. Anim. Sci. 78: 1816-1828.

Mariscal-Landin, G., B. Seve, Y. Colleaux and Y. Lebreton. 1994. Endogenous amino nitrogen collected from pigs with end-toend ileorectal anastomosis is affected by the method of estimation and altered by dietary fiber. J. Nutr. 136-146.

Noblet, J., H. Fortune, C. Dupire and S. Dubios. 1993. Digestible, metabolizable and net energy values of 13 feedstuffs for growing pigs. Anim. Feed Sci. Technol. 42:131-149.

Noblet, J., H. Fortune, X. S. Shi and S. Dubios. 1994. Prediction of net energy value of feeds for growing pigs. J. Anim. Sci. 72: 344-354.

Noblet, J., C. Karege, S. Dubois and J. van Milgen. 1999. Metabolic utilization of energy and maintenance requirements in growing pigs: Effects of sex and genotype. J. Anim. Sci. 77: 1208-1216.

Noblet, J. 2000. Digestive and metabolic utilization of energy in swine: Application to energy evaluation systems. J. Appl. Anim. Res. 17:113-132.

Noblet, J. and J. van Milgen. 2004. Energy value of pig feeds: Effect of pig body weight and energy evaluation system. J. Anim. Sci. 82(E. Suppl.):E229-E238.
NRC. 1998. Nutrient requirements of swine. (10 $0^{\text {th }}$ ed.) Natl. Acad. Press, Washington, DC, USA

Nyachoti, C. M., C. F. M. de Lange, B. W. McBride and H. Schulze. 1996. Significance of endogenous gut nitrogen losses in the nutrition of growing pigs: A review. Canadian J. Anim. Sci. 149-163.

Pettigrew, J. E. and R. L. Moser. 1991. Fat in swine nutrition. In: Swine Nutrition ( Ed. E. R. Miller, D. E. Ullrey and A. J. Lewis). pp. 133-146. Butterworth-Heinemann. Stoneham. MA.

Pig Improvement Company. 2008. PIC nutrient specifications. Hendersonville, $\mathrm{TN}$.

Schinckel, A. P. and C. F. M. de Lange. 1996. Characterization of growth parameters needed as inputs for pig growth models. J. Anim. Sci. 74:2021-2036.

Schinckel, A. P., M. E. Einstein, S. Jungst, C. Booher and S. Newman. 2009a. Evaluation of different mixed model nonlinear functions to describe the body weight growth of pigs of different sire and dam lines. Prof. Anim. Sci. 25:307-324.

Schinckel, A. P., M. E. Einstein, S. Jungst, C. Booher and S. Newman. 2009b. Evaluation of different mixed model nonlinear functions to describe the feed intakes of pigs of different sire and dam lines. Prof. Anim. Sci. 25: 345-359.

Schinckel, A. P., M. E. Einstein, S. Jungst, J. O. Matthews, B. Fields, C. Booher, T. Dreadin, C. Fralick, S. Tabor, A. Sosnicki, E. Wilson, R. D. Boyd and S. Newman. 2012. The impact of feeding diets of high or low energy concentration on carcass measurements and the weight of primal and subprimal lean cuts. Asian-Aust. J. Anim. Sci. (submitted)

Schinckel, A. P., D. C. Mahan, T. G. Wiseman and M. E. Einstein. 2008. Impact of alternative energy systems on the estimated feed requirements of pigs with varying lean and fat tissue growth rates when fed corn and soybean meal-based diets. Prof. Anim. Sci. 24:198-207.

Weber, T. E., B. T. Richert, M. A., Belury, Y. Gu, K. Enright and A. P. Schinckel. 2006. Evaluation of the effects of dietary fat, conjugated linoleic acid, and ractopamine on growth performance, pork quality, and fatty acid profiles in genetically lean gilts. J. Anim. Sci. 84:720-732.

Whittemore, C. T. 1997. An analysis of methods for the utilisation of net energy concepts to improve the accuracy of feed evaluation in diets for pigs. Anim. Feed Sci. Technol. 68:89-99. 